\title{
Study of Early Intervention Effect Using Korean Auditory, Language, and Cognitive Rehabilitation for Infants with Hearing Loss
}

\author{
Heesoon Yoo ${ }^{1}$, Dokyun Kim¹, Jinsook Kim ${ }^{1,2}$ \\ 'Department of Speech Pathology and Audiology, Graduate School, Hallym University, Chuncheon, Korea \\ ${ }^{2}$ Division of Speech Pathology and Audiology, Research Institute of Audiology and Speech Pathology, \\ College of Natural Sciences, Hallym University, Chuncheon, Korea
}

\author{
청각장애 영유아의 청각언어인지재활(KARI)을 이용한 조기 중재 효과 연구 \\ 유희순 ${ }^{1}$ 김도균 ${ }^{1}$ 김진숙,2 \\ 한림대학교 일반대학원 언어병리청각학과', 한림대학교 자연과학대학 언어청각학부 · 청각언어연구소 ${ }^{2}$
}

\begin{abstract}
Purpose: The present study was aimed to identify the effect of early intervention using Korean Auditory, language, and cognitive Rehabilitation for Infants (KARI) program for the hearing-impaired infants. Methods: The KARI program composed with the evaluation materials, parent education and counseling materials, professional guidelines were applied to 12 infants from 1 to 24 months old once a week. The evaluation materials were Korean version of LittIEARS ${ }^{\circledast}$ Auditory Questionnaire (LEAQ-K), Categories of Auditory Performance (CAP), Infant-Toddler Auditory \& Communicative Behavioral Checklist (IT-ACBC), Sequenced Language Scale for Infants (SELSI), Korean MacArthurBates Communicative Development Inventories (K MB CDI), and Communication and Symbolic Behavior Scales: Developmental Profile (CSBS DP). Results: The scores of LEAQ-K, CAP, and IT-ACBC were enhanced from 23.27 to $27.55,4.14$ to 4.36 , and 48.05 to 61.53 . SELSI scores in receptive and expressive languages increased from 24.76 and 19.59 to 31.12 and 24.41. K MB CDI scores increased in expressive and receptive vocabularies and gesture and play from $10.00,62.60$ and 23.60 to 59.00, 111.00 and 47.80. CSBS DP scores increased from 37.50 to 46.71 . After applying KARI, the early intervention effects were shown in scores of the evaluation materials with the statistical significances $(p<0.05)$ in LEAQ-K, IT-ACBC, SELSI, receptive vocabulary in K MB CDI, and CSBS DP checklist. Conclusion: The current results support that KARI is an effective rehabilitation tool for the early intervention to the hearing-impaired infants. When given the suitable rehabilitation at the early stage, the hearing-impaired infants can develop the early communication skills near to normal range.
\end{abstract}

Key Words: Infants, Aural rehabilitation, Korean Auditory language and cognitive Rehabilitation for Infants (KARI), Early Intervention, Hearing loss.

Received: April 6, 2019 / Revised: April 15, 2019 / Accepted: April 15, 2019

Correspondence: Jinsook Kim, Division of Speech Pathology and Audiology, Research Institute of Audiology and Speech Pathology, College of Natural Sciences, Hallym University, 1 Hallymdaehak-gil, Chuncheon 24252, Korea Tel: +82-33-248-2213 / Fax: +82-33-256-3240 / E-mail: jskim@hallym.ac.kr

\section{INTRODUCTION}

세계보건기구(World Health Organization, WHO)는 전 세 계에서 난청으로 고통을 받는 사람의 수가 3억 6,000만 명으로 전체 인구의 $5 \%$ 에 달하고, 이 중 영유아 및 아동은 3,200 만 명

(c) This is an Open Access article distributed under the terms of the Creative Commons Attribution Non-Commercial License (https://creativecommons.org/licenses/by-nc/4.0) which permits unrestricted non-commercial use, distribution, and reproduction in any medium, provided the original work is properly cited.
에 이른다고 보고하고 있다(WHO, 2013). 특히, 만 15세 이하의 아동 청각장애 중 $60 \%$ 는 원인을 알고 대처할 수 있으나 $40 \%$ 는 선천적으로 나타나는 불가피한 난청임을 시사하였는데 이러 한 선천적인 난청은 대부분이 영유아에게 나타나고, 출현율은 1,000명당 1 3명으로 여러 가지 선천성 질병 중에도 매우 높은 출현율이다(National Institutes of Health, 1993). 우리나라도 9 세 이전 난청 출현율은 국제적으로 나타나는 선천적인 난청의 출현율과 유사한 것으로 보고되었다(Kim et al., 2014). 
영유아 청각장애의 조기 발견과 중재를 1994년부터 연구한 Joint Committee on Infant Hearing (JCIH) 보고서는 미국에 서 태어나는 신생아 중 $95 \%$ 가 청각선별검사를 받고 있으나, 선 별검사를 통과하지 못한 신생아 중 약 $50 \%$ 가 청력 선별을 확 진하는 적절한 추후 검사와 중재 서비스를 받지 못하고 있는데 그 이유는 청각장애 영유아에게 조기 중재를 실시할 수 있는 전 문 인력이 부족하기 때문이라고 밝히고 있다(American Academy of Pediatrics \& JCIH, 2007). 더욱이 청각장애는 인지와 언어 기능 등이 정상적으로 발달할 수 있는 기본 자극인 청각 자극의 부족함을 초래하므로 전체적인 발달에 매우 중요한 시 기인 생후 1 2년 동안의 뇌가소성 형성에 치명적인 영향을 미 칠 수 있고(Kim et al., 2012), 따라서 조기 중재는 의사소통, 지 능, 사회적응력, 행동능력 등의 수행력도 20 40\%ile 상승시킬 수 있다고 보고하고 있다(Yoshinaga-Itano et al., 2000). WHO 도 난청은 아동에게 언어 발달 지체나 사회적 고립 등을 가져올 수 있으므로 예방을 위한 방법으로 모자 건강 관리, 청각 전문 가의 개입, 약물 및 환경소음의 관리, 영유아 및 아동의 청각선 별검사, 청각보조기 착용과 의사소통을 위한 치료 등을 권고하 고 있다(WHO, 2013).

청각장애의 성공적인 조기재활은 부모나 가족이 일상생활에서 중재에 참여하므로 특히 가족들의 지지가 필요한데(Noh, 2014), 이러한 가족 중심의 구조화된 재활 프로그램은 세계적으로 여 러 개가 소개되었고 그 효과를 입증받았다. 유타 주립대학의 Sensory Kids Impaired Home Intervention (SKI-HI) 연구소 에서는 연구소의 이름과 동일한 SKI-HI라는 청각재활 프로그 램을 운영하고 있는데, 영유아기부터 5세까지의 난청 아동을 대상으로 가족 내 소통을 강조하는 다양한 방법을 제시하고 있다(Watkins et al., 2004). 인공와우 제조사인 Cochlear 사에 서 사용하는 Learn to talk around the clock도 인공와우 착용 후 3세까지 적용할 수 있는 12 개의 일상생활 상황별로 특징적 행동을 8단계로 세분화하고 각 단계에 맞는 듣기와 말하기를 유도할 수 있는 가족 중심의 프로그램을 제시하고 있다(Rossi, 2003). 덴버 대학에서 시작하여 콜로라도주 전체에서 시행되고 있는 Colorado Home Intervention Program도 6개월 이전에 난청을 판정받고 재활을 시작한 경우 조기중재의 우수한 효과 를 보고하였다(Yoshinaga-Itano \& Apuzzo, 1998). 퍼듀 대학 에서는 인공와우 이식수술 아동의 부모나 전문가가 발성 모델 을 제시하여 발성 및 조음 발달을 향상시키도록 개발된 프로그 램인 Short Periods of Prelinguistic Input을 소개하고 있는데, 홈페이지(http://www.vocaldevelopment.com/sppivideo.htm) 에 조기중재에 필요한 내용과 발성 종류, 기준, 조기중재의 예 등을 동영상 자료로 제공하고 있다(Ertmer et al., 2002). 그 외 아기의 구어 습득을 위하여 부모의 재활 참여와 활동을 강조한
재활방법으로 개발된 청각구어법(Auditory Verbal Therapy)은 일상생활에서 청각보조기기의 사용을 최적화하여 가장 자연스 러운 듣기 환경을 강조한 프로그램이다(Rhoades \& Duncan, 2016). 그러나 이러한 외국의 청각장애를 위한 조기재활 프로그 램은 언어와 문화적 차이로 국내에서 그대로 적용할 수 없으므 로 국내의 청각장애 영유아를 위한 구조화된 조기재활 프로그 램을 적용하지 못하고 있는 실정이다. 최근에 영유아의 조기 청 능재활을 연구한 소수의 사례가 보고되었는데(Lee \& Cho, 2011; Yoon et al., 2016) 연구자들은 수년간의 경험에서 청각장 애 영유아의 조기중재는 단순한 청능재활이나 언어재활이 아 닌 조기의 청감각을 활용하여 인지와 언어를 함께 발달시키는 과정임을 인식하여 한국형 영유아 청각언어인지재활(Korean Auditory, language, and cognitive Rehabilitation for Infant, $\mathrm{KARI}$ )이라고 정의하고 명명하였다.

$\mathrm{KARI}$ 는 회기 전 점검 목록, 전문가용 자료, 부모 교육 자료 등 크게 세 가지로 구성되어 있으며, 듣기, 언어 및 사회적 의사 소통, 전반적 발달, 발성 및 조음 등 4 개 영역의 수행능력 평가 로 발달 과정을 효율적으로 검증할 수 있도록 설계되어 있다. 듣 기 발달 평가는 The Korean version of LittlEARS ${ }^{\circledR}$ Auditory Questionnaire (LEAQ-K) (Sohn et al., 2015), Categories of Auditory Performance (CAP) (Archbold et al., 1995)를 사용 하였다. 또한 KARI 개발 과정에서 국내 영유아의 청각 및 의 사소통 행동을 간편히 점검할 수 있는 검사도구로 청각 발달과 의사소통 행동에 관련된 체크리스트인 영유아 청각-의사소통 행동 체크리스트(Infant-Toddler Auditory \& Communicative Behavioral Checklist, IT-ACBC) (Park \& Kim, 2016b)를 개 발하여 사용하였다.

언어 및 사회적 의사소통 영역은 기존 문헌을 토대로 취학 전 아동의 수용 및 표현 언어 척도(Preschool Receptive-expressive Language Scale) (Kim et al., 2003b)와 아기 언어 발 달의 전반적인 내용을 검사하는 한국어 문항으로 개발된 수용 및 표현 언어 평가인 영유아 언어발달검사(Sequenced Language Scale for Infants, SELSI) (Kim et al., 2003a), 표준화된 단어의 이해 및 표현 어휘 검사인 맥아더 베이츠 의사소통 발달 목록(MacArthur Bates Communicative Development Inventories, MB CDI) (Fenson et al., 1993)을 한국어판으로 구성한 Korean MB CDI (K MB CDI) (Pae \& Kwak, 2011), 의사소통 및 상징행동 척도: 발달 개요(Communication and Symbolic Behavior Scales: Developmental Profile, CSBS DP)의 체크리 스트(checklist)와 행동 샘플(behavior sample)을 사용하였다 (Wetherby \& Prizant, 2002). 체크리스트는 엄마의 보고에 기 초하여 발달적 평가를 위한 선별검사로 6 24개월 영유아를 대 상으로 하고, 행동 샘플은 검사자가 직접 관찰하여 행동 샘플 
을 분석하고 진단하기 위한 검사로 12 24개월 영유아를 대상 으로 한다. CSBS DP 체크리스트는 Lee \& Jang(2004)이 최초 로 번역을 하였으나 번역 내용이 부적절하고 문항 수도 24개에 서 18 개로 줄여 적절한 번역본으로 사용할 수 없었다. 따라서 KARI 연구팀 연구자들(박혜진과 김진숙)이 저자의 동의를 얻 어 번역본을 제작하여 사용하였다(Appendix 1). 전반적 발달 에 대한 평가는 보건복지부와 질병관리본부에서 4 71개월 한 국 영유아의 대근육운동, 소근육운동, 인지, 언어, 사회성, 자조 의 발달 영역을 평가하는 한국 영유아 발달선별검사(Korean Developmental Screening Test for Infants \& children, KDST) (Eun \& Chung, 2014)가 사용되었다. 발성 및 조음 평가 는 최근 KARI 연구팀에 의해 개발된 영유아의 발성 및 조음 발달 목록(Korean Infant Vocal and Articulatory Development List, KIVAD) (Kim et al., 2017)을 사용하였다.

본 연구는 12명의 1 24개월 청각장애 영유아들에게 KARI 프로그램 적용 전후에 LEAQ-K, CAP, IT-ACBC, SELSI, K $\mathrm{MB} \mathrm{CDI}, \mathrm{CSBS}$ DP 체크리스트와 행동 샘플 평가를 실시하여 청능재활 프로그램의 효율성을 분석하고 KARI 프로그램이 체 계화된 청각장애 영유아의 조기중재 프로그램으로 사용될 가 능성을 확인하고자 하였다. 구체적으로 제시된 평가 자료로 조 기중재 전후의 분석을 통하여 영유아의 인지 발달을 향상시키 는 구조화된 조기중재 프로그램 적용이 청각장애 영유아의 청 각.언어 발달뿐 아니라 전반적인 발달에 긍정적인 영향을 미칠 수 있는 점을 확인하고자 하였다.

\section{MATERIALS AND METHODS}

\section{연구 대상}

본 연구는 부모에게 동의서를 받은 후 2015년 7월부터 2017년 9월까지 12 명의 청각장애 영유아가 참여하였다. KARI 프로그램 으로 조기 중재를 시작한 연령은 평균 10.3개월[standard deviation (SD): 6.02개월]이었고, 생활연령 24개월이 될 때까지 평균 8.1개월(SD: 4.64개월) 동안 재활을 진행하였다. 여아가 6명, 남 아가 6명이었고, 청각보조기기로 8명이 양측 보청기를, 2 명이 양 측 인공와우를 착용하였다. 난청의 정도는 경도 1 명, 중도 3 명, 중 고도 2 명, 고도 4명, 심도 1명, 일측성 심도 난청 1명이었다(Table 1). 이 중 일측성 난청과 양측 경도 난청인 영유아 2 명은 청각보 조기기를 착용하지 않았다.

\section{$\mathrm{KARI}$ 프로그램의 구성}

적어도 매주 1 회기씩 각 회기별로 60 90분의 중재를 KARI 프로그램을 적용하여 실시하였다. KARI는 회기 전 점검 목록, 전문가용 자료, 부모 교육 자료로 구성하였다(Appendix 2). 회 기 전 점검 목록 중 ‘회기 계획 및 보고서'는 매 회기마다 제시 하고 확인하여야 할 자료와 장-단기 계획, 재활의 목표, 도구, 결과 등을 한꺼번에 볼 수 있도록 정리하여 전문가가 쉽게 활 용할 수 있도록 하였다(Appendix 3). 한 장으로 정리된 이 '회 기 계획 및 보고서'는 '궁금해요, '우리 아이와 매일매일 어떻게 말할까요?, '단동십훈, '짧고 재미있게 받아들이는 모델링 기법 (Short Fun Input for Modeling, SFIM)' 같은 부모 교육 자료 가 언제 부모에게 제공되었는지 회기마다 확인할 수 있도록 하 였다. 이 중 '궁금해요는 부모가 가정에서 청각보조기기나 재활 과 관련하여 궁금한 내용을 기록하여 주간별로 전문가에게 질

Table 1. Information of children participating in KARI program (at October 2018)

\begin{tabular}{|c|c|c|c|c|c|c|c|}
\hline Subject & Months of age & Sex & Hearing loss & Hearing device & $\begin{array}{l}\text { Fitting months } \\
\text { for } \mathrm{CI} / \mathrm{HA}\end{array}$ & $\begin{array}{l}\text { Starting months } \\
\text { for KARI }\end{array}$ & $\begin{array}{c}\text { Number } \\
\text { of Assessments }\end{array}$ \\
\hline A & 27 & $\mathrm{~F}$ & Bilateral moderate & Bilateral HA & 4 & 4 & 3 \\
\hline \multirow[t]{2}{*}{$\mathrm{B}$} & 30 & $\mathrm{~F}$ & Rt: Moderate & Bilateral HA & 6 & 8 & 4 \\
\hline & & & Lt: Moderate to severe & & & & \\
\hline $\mathrm{C}$ & 38 & $\mathrm{~F}$ & Bilateral moderate & Bilateral HA & 20 & 21 & 3 \\
\hline $\mathrm{D}$ & 31 & M & Bilateral moderate to severe & Bilateral HA & 7 & 8 & 4 \\
\hline $\mathrm{E}$ & 48 & M & Unilateral profound (Rt) & - & - & 9 & 6 \\
\hline $\mathrm{F}$ & 43 & M & Bilateral mild & - & - & 5 & 6 \\
\hline G & 46 & $\mathrm{~F}$ & Bilateral severe & Bilateral CI & 13 & 14 & 4 \\
\hline $\mathrm{H}$ & 45 & M & Bilateral moderate & Bilateral HA & 12 & 18 & 2 \\
\hline I & 34 & M & Bilateral severe & Bilateral HA & 6 & 6 & 3 \\
\hline $\mathrm{J}$ & 33 & $\mathrm{~F}$ & Bilateral severe & Bilateral HA & 8 & 8 & 2 \\
\hline K & 32 & $\mathrm{~F}$ & Bilateral severe & Bilateral HA & 4 & 4 & 4 \\
\hline $\mathrm{L}$ & 39 & M & Bilateral profound & Bilateral CI & 12 & 20 & 2 \\
\hline
\end{tabular}

KARI: Korean Auditory, language, and cognitive Rehabilitation for Infants, CI: cochlear implant, HA: hearing aid 
문하고 전문가는 답변을 적어 전하는 알림장 같은 역할을 하도 록 하였다.

전문가용 자료 중 $\mathrm{KIVAD}$ 는 11 개의 월령 구간, $1 \sim 3,4 \sim 5$, 6 7, 8 9, 10 11, 12 13, 14 15, 16 17, 18 19, 20 21, 22 24로 나누어 구간별 발성 및 조음 발달 영역으로 구분하여 정상 발 달 영유아들이 발화하는 발성 및 조음에 대한 산출 시기를 확 인하였다(Kim et al., 2017). 그에 따른 재활 목표를 설정할 수 있는 도구로 활용하여 '기간 점검표'를 작성해 사용하였고 1 3 개월 구간의 '기간 점검표'를 Appendix 4에 제시하였다. 기간 점검표는 해당 기간에 아기가 스스로 한 말과 엄마가 모델링으 로 제시한 말, 아기가 따라 한 말 등을 KIVAD의 조음 발달 단 계를 중심으로 기록하도록 하였다. 그 외 아기의 청각 상태와 현재 청각보조기기가 잘 작동하는지 확인할 수 있는 3 개의 모 음 / / /, / / / / T/와 3개의 자음 /음/, /스/, /쉬/로 구성된 Ling 6 sound 검사를 매 회기마다 실시하고 회기 계획 및 보고서의 체 크 칸에 실시 내용을 표기할 수 있도록 하였다(Park \& Kim, 2016a). '영유아의 청각/언어재활 가이드라인'은 전문가가 영유아 의 청각언어인지재활을 효율적으로 실행할 수 있는 실질적 지 침으로 제시하였는데, 청각보조기기, 영역 발달 평가, 재활 진 행 및 환경, 소리자극의 종류로 구성하였다. 각 회기마다 듣기 능력을 최적화하도록 아기가 사용하는 보장구를 점검할 수 있 는 청음기, 예비 배터리, 배터리 점검기 및 보청기 관리도구, 보 장구가 회기를 시작할 때 작동하지 않을 경우 대체로 사용할 수 있는 상자보청기 등을 구비하도록 하였다.

부모 교육 자료는 스마트 육아법으로 우리나라의 정서를 반 영하고 부모와 아기의 스킨십을 바탕으로 뇌 발달을 촉진시킬 수 있는 애착육아법을 활용하였다(Yoo \& Kim, 2018). 또한 불 아불아(弗亞弗亞), 시상시상(詩想詩想), 도리도리(道理道理), 지암지암(持闇持闇), 곤지곤지(坤地坤地), 섬마섬마(西摩西摩), 업비업비(業非業非), 아함아함(亞合亞合), 짝짝궁짝짝궁(作作 弓作作弓), 질라아비 휠휠의(羅呵備 活活議)로 구성된 단군시 대부터 내려오는 상호작용이 강조된 우리나라 전통놀이와 접 목된 '단동십훈'을 적용하였다. '단동십훈'은 특히 익숙한 동작 과 운율이 반복적으로 제시되어 모방이 쉽기 때문에 조기재활 에 매우 효율적이다. 더 나아가 일상생활에서 부모와 나누는 상호작용과 대화 상황에서 아기가 스스로 결정하고 상황별 놀 이를 이끌 수 있도록 아기의 흥미와 수준을 존중하며 기다려 주기, 한 박자 늦게 반응하기, 답은 아기가 하도록 하게 하기 등 부모가 직접 실천할 수 있는 '자기주도형 아기로 키워요'와 아기 가 쉽고 즐겁게 발성이나 목표 음소를 따라 할 수 있는 효율적 인 모델링 방법으로 고안된 방법인 '짧고 재미있게 받아들이는 모델링 기법(SFIM)' 등을 포함하였다. 또한, 일상생활에서 부딪 힐 수 있는 16 가지 상황-아침에 일어날 때 말하기', '기저귀 갈
며 말하기', '목욕 전후에 말하기', '마사지하며 말하기', '젖(우유) 먹이며 말하기', '옷 입고 벗을 때 말하기', '아이에게 밥 먹이며 말하기', '책 읽기', '공 가지고 놀기', '아이 인형이나 곰 인형 가지 고 놀기', '퍼즐 가지고 놀기', '소꿉놀이하기', '놀이터에서 놀기', '색깔찰훍 놀이하기', '빨래하기', '산책하기'-에서 구체적인 놀이 와 상황에 따라 적절한 말하기 방법이 소개된 '우리 아이와 매 일매일 어떻게 말할까요'와 아기에게 엄마가 애기할 때, 눈맞춤 과 긍정적인 반응을 통해 상호작용을 유도하고 아기의 발성과 행동을 관찰하고 민감하게 반응을 하며 칭찬을 통해 아기의 발성이나 조음을 효율적으로 유도할 수 있으며, 소리와 언어가 풍부한 좋은 환경을 조성할 수 있는 방법을 제시한 '우리 아이 의 청각/언어 발달 촉진법 등도 추가적으로 제시되었다(Appendix 5). 이 모든 부모 교육 자료의 내용은 중재 과정에서 실 시되었고 자세한 내용을 부모에게 설명하고 자료로 제시하여 가족과 함께 내용을 공유하고 반복적으로 확인하고 부모가 따 라할 수 있도록 하였다.

\section{평가 도구}

KARI 프로그램을 적용하기 전 기초선 평가를 한 후, 진전 평가는 매 2 3개월마다 실시하였다. 듣기, 언어 및 사회적 의사 소통, 전반적 발달, 발성 및 조음 등 네 개의 영역을 평가하는 총 9개 도구로 평가를 실시하였다(Table 2).

처음 KARI를 시작하기 전 총 9 개의 평가도구를 검사자가 직접 실시할 수 있는 경우는 직접 실시하였으나 검사 시간이 부족한 경우 LEAQ-K, CAP, IT-ACBC, SELSI, K MB CDI 와 CSBS DP 체크리스트, K-DST의 평가도구는 실시 방법에 대한 자세한 안내와 함께 부모가 직접 검사지에 기록하도록 안 내하였다. K-DST를 제외한 모든 검사의 연령 기준은 청각보조 기기를 사용한 후의 듣기 연령이었으나, 청각보조기기를 사용 하지 않은 두 영유아(E와 F; Table 1)는 생활 연령과 듣기 연령 이 같아 생활 연령을 기준으로 결과를 제시하였다.

\section{통계 분석}

청각장애 영유아의 중재 전후의 점수 변화량을 분석하고 정 상 영유아 규준 점수가 검사 매뉴얼에 제시된 경우, 중재 전후 에 해당하는 해당 연령대의 정상 영유아 점수와의 변화량을 비 교하였다. 대상자가 소수이고 평가 결과가 정규 분포를 따르지 않아 통계 분석은 비모수 검정인 Wilcoxon 검정을 사용하였으 며 통계 프로그램은 Windows용 SPSS version 18.0 (SPSS Inc., Chicago, IL, USA)을 사용하였다. 
Table 2. A summary of evaluation areas and assessment tools

\begin{tabular}{lll}
\hline \multicolumn{1}{c}{ Evaluation areas } & \multicolumn{1}{c}{ Assessment tools } & \multicolumn{1}{c}{ Authors } \\
\hline Auditory development & Korean version of LittlEARS ${ }^{\circledR}$ Auditory Questionnaire & Sohn et al. (2015) \\
& Categories of Auditory Performance & Archbold et al. (1995) \\
& Infant-Toddler Auditory \& Communicative Behavioral Checklist & Park \& Kim (2016b) \\
Language and communication & Sequenced Language Scale for Infants & Kim et al. (2003a) \\
development & Korean MacArthur-Bates Communicative Development & Fenson et al. (1993) \\
& Inventories & Pae \& Kwak (2011) \\
& Communication and Symbolic Behavior Scales: Developmental & Wetherby \& Prizant (2002) \\
& Profile behavior sample & Wetherby \& Prizant (2002) \\
& Communication and Symbolic Behavior Scales: Developmental & translated by H. Park and J. Kim \\
Developmental screening & Profile checklist & Eun \& Chung (2014) \\
Vocal and articulatory & Korean Developmental Screening Test for Infants \& Children & Kim et al. (2017) \\
development & & \\
\hline
\end{tabular}

Table 3. Comparison of statistical results for 7 measurements

\begin{tabular}{llcc}
\hline \multicolumn{1}{c}{ Assessment tools } & Specific classsification & Pre/post scores & Normal/hearing impaired change scores in corresponding period \\
\hline LEAQ-K & Total & $\dagger$ & - \\
CAP & Total & - & - \\
IT-ACBC & Total & $\neq$ & - \\
SELSI & Receptive language & $\dagger$ & - \\
& Expressive language & $*$ & - \\
K MB CDI & Expressive vocabulary & - & - \\
& Receptive vocabulary & $*$ & - \\
CSBS DP checklist & Gesture and play & - & $*$ \\
& Social composite & $*$ & - \\
& Speech composite & $\dagger$ & - \\
CSBS DP behavior sample & Social composite & + & - \\
& Speech composite & - & - \\
& Symbolic composite & - & - \\
\hline
\end{tabular}

${ }^{*} p<0.05,{ }^{\dagger} p<0.01,{ }^{\ddagger} p<0.001$. LEAQ-K: Korean version of LittlEARS ${ }^{\bullet}$ Auditory Questionnaire, CAP: Categories of Auditory Performance, IT-ACBC: Infant-Toddler Auditory \& Communicative Behavioral Checklist, SELSI: Sequenced Language Scale for Infants, K MB CDI: Korean MacArthur-Bates Communicative Development Inventories, CSBS DP: Communication and Symbolic Behavior Scales: Developmental Profile

\section{RESULTS}

청각장애 영유아의 중재 전후의 모든 평가 자료 점수 변화량 과 정상 영유아 규준 점수가 검사 매뉴얼에 제시된 경우, 중재 전후에 해당하는 해당 연령대의 정상 영유아 점수 변화량과 비 교에 대한 전체 통계 분석 자료와 이에 대한 평가 영역별 자세 한 결과는 Table 3에 제시되어 있다.

\section{청각 발달}

듣기 평가도구로 실시한 청각장애 영유아들의 LEAQ-K 재 활 전후 점수는 23.27점(SD: \pm 8.72)에서 27.55점(SD: \pm 7.53$)$ 으로 증가하였으며 통계적으로 유의미한 차이를 보였다 $(p<$
0.05). 해당 기간의 동일 연령 정상 영유아의 규준 평균은 17.51 점(SD: \pm 8.08$)$ 에서 21.98점(SD: \pm 6.92)으로 청각장애 영유 아의 재활 전후 점수 증가량은 4.23점이었고, 해당 기간 동안 정 상 영유아의 동일 연령 규준 점수 증가량은 4.47점이었으며 두 그 룹의 증가량은 통계적으로 유의미한 차이를 보이지 않았다 $(p>$ 0.05). K (Table 1)를 제외한 모든 영유아는 재활 후 평가에서 동 일 연령 영유아의 평균과 비슷하거나 높은 수행력을 보였다.

청각 및 의사소통 행동 발달 평가를 위하여 실시한 청각장애 영유아의 $\mathrm{CAP}$ 재활 전후 단계는 4.14단계(SD: \pm 1.58$)$ 에서 4.36단계(SD: \pm 1.59$)$ 로 상승하였으나, 통계적으로 유의미한 차 이를 보이지 않았다 $(p>0.05)$. 듣기 및 의사소통 행동 발달 관 련 평가를 위하여 실시한 청각장애 영유아의 IT-ACBC의 재활 
전후 점수는 48.05\%(SD: \pm 20.56)에서 61.53\%(SD: \pm 19.46$)$ 로 증가하여 통계적으로 유의미한 결과를 보였다 $(p<0.05)$. 동일 연 령의 정상 영유아 규준 평균은 해당 기간 전후의 점수는 $35.00 \%$ (SD: \pm 21.38$)$ 와 46.46\%(SD: \pm 22.52$)$ 로 청각장애 유아들의 재 활 전후 점수 증가량은 $13.48 \%$ 였고 동일 연령의 정상 영유아 규 준 증가량은 $11.46 \%$ 로 $2.02 \%$ 높은 증가량을 보였으나 두 그룹의 증가량은 통계적으로 유의미하게 다르지 않았다 $(p>0.05)$.

\section{언어 및 의사소통 발달}

언어 발달능력을 평가하기 위하여 실시한 청각장애 영유아의 SELSI 재활 전후 수용 언어 점수는 24.76점(SD: \pm 12.08 )에서 31.12점(SD: \pm 13.21)으로, 표현 언어 점수는 19.59점(SD: \pm 9.91)에서 24.41점(SD: \pm 11.17)으로 증가하였고 모두 통계적으 로 유의미한 차이를 보였다 $(p<0.05)$. 검사 매뉴얼에 제시된 기준 점수는 4 개월부터 제시되어 4 개월 이후의 점수를 해당 연 령과 비교하였을 때 재활 전후의 연령에 해당하는 정상 영유아 의 수용 언어 점수는 18.53점(SD: \pm 11.89$)$ 과 24.85점(SD: \pm $12.70)$ 이었고 표현 언어 점수는 17.00점(SD: \pm 9.93)과 22.97점
(SD: \pm 11.14 )이었다. 청각장애 영유아의 재활 전후 점수 증가 량은 수용 언어는 6.36점, 표현 언어는 4.82점이었고, 해당 기간 동안 정상 영유아의 동일 연령 규준 점수 증가량은 수용 언어 가 6.32점이고 표현 언어가 5.97점이었으나, 두 그룹의 증가량은 통계적으로 유의미하게 다르지 않았다 $(p>0.05)$.

어휘 발달능력을 평가하기 위하여 실시한 청각장애 영유아의 $\mathrm{K} \mathrm{MB} \mathrm{CDI는} \mathrm{재활} \mathrm{전후} \mathrm{이해} \mathrm{어휘} \mathrm{점수는} \mathrm{62.60점(SD:} \pm 57.71)$ 에서 111.00점(SD: \pm 96.91)으로, 표현 어휘 점수는 10.00점(SD: \pm 16.05)에서 59.00점(SD: \pm 119.11)으로, 제스처와 놀이 점수 는 23.60점(SD: \pm 19.58$)$ 에서 47.80점(SD: \pm 16.24$)$ 으로 모든 영역에서 점수가 증가하였고 통계적으로 유의미한 차이를 보였 다 $(p<0.05)$. 검사 매뉴얼에 제시된 점수는 8 개월부터 제시되 어 8 개월 이후의 점수를 해당 연령과 비교하였을 때 재활 전후 의 연령에 해당하는 정상 영유아의 이해 어휘 점수는 36.00점 (SD: \pm 16.61$)$ 과 72.40점(SD: \pm 25.195$)$, 표현 어휘 점수는 4.40점(SD: \pm 2.41$)$ 과 9.80점(SD: \pm 3.83$)$, 제스처와 놀이 점수 는 25.20점(SD: \pm 15.52$)$ 과 40.40점(SD: \pm 3.29)이었다. 청각장 애 영유아의 재활 전후 점수 증가량은 이해 어휘 점수가 48.40

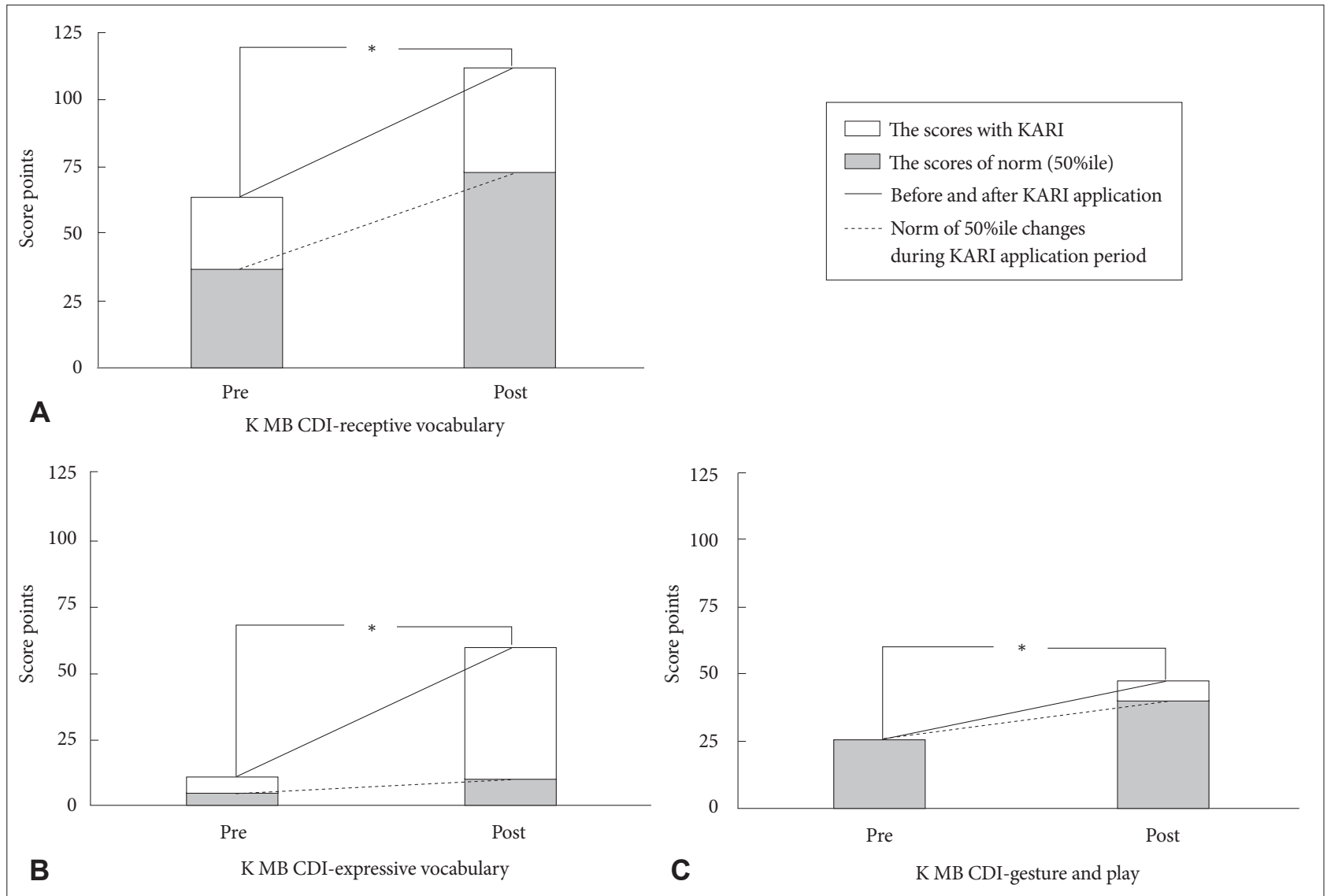

Figure 1. K MB CDI scores for the pre- and post-rehabilitations. A: K MB CDI-receptive vocabulary. B: K MB CDI-expressive vocabulary. C: $\mathrm{K}$ MB CDI-gesture and play. The grey bars and dotted lines show the normal means provided by the manual and the white bars and solid lines show the scores of the hearing-impaired babies. ${ }^{*} p<0.05 . \mathrm{K} \mathrm{MB}$ CDI: Korean MacArthur-Bates Communicative Development Inventories, KARI: Korean Auditory, language, and cognitive Rehabilitation for Infants. 
점, 표현 어휘 점수가 49.00점, 제스처와 놀이 점수가 29.20점이 었고, 해당 기간 동안 정상 영유아의 동일 연령 규준 점수의 증 가량은 이해 어휘 점수가 9.45점, 표현 어휘 점수가 5.7점, 제스처 와 놀이 점수가 6.7점이었다. 따라서 청각장애 영유아의 점수가 이해 어휘, 표현 어휘, 제스처와 놀이에서 각각 36.40점, 5.40점, 15.20점씩 더 높게 나타났고 이해 어휘와 표현 어휘는 통계적으 로 유의미한 차이를 보이지 않았으나 $(p>0.05)$ 제스처와 놀이 점 수는 통계적으로 유의미한 차이를 보였다 $(p<0.05)$ (Figure 1).

사회적 의사소통 발달능력을 평가하기 위하여 실시한 청각 장애 영유아의 CSBS DP 체크리스트의 재활 전 사회적 행동 점 수는 21.14점(SD: \pm 6.01), 언어 표현 점수는 6.57점(SD: \pm 3.86 , 상징행동 점수는 9.79점(SD: \pm 4.79)에서 재활 후 각각 24.14점 (SD: \pm 2.77), 9.36점(SD: \pm 2.62), 13.21점(SD: \pm 3.75)으로 모 든 영역에서 점수가 증가하였고 통계적으로 유의미한 차이를 보였다 $(p<0.05)$. 검사 매뉴얼에 제시된 본 연구 대상자들의 재활 전후 연령에 해당하는 정상 영유아의 사회적 행동 점수는 16.25점(SD: \pm 5.60)과 19.21점(SD: \pm 4.11$)$, 언어 표현 점수는 6.93점(SD: \pm 3.19)과 8.86점(SD: \pm 2.61), 상징행동 점수는
8.57점(SD: \pm 4.27)과 10.86점(SD: \pm 3.73)이었다. 청각장애 영 유아의 재활 전후 점수 증가량은 사회적 행동 점수가 3.00점, 언어 표현 점수가 2.79점, 상징행동 점수가 3.43점이었고 해당 기간 동안 정상 영유아의 동일 연령 규준 점수 증가량은 사회 적 행동 점수가 2.96점, 언어 표현 점수가 1.93점, 상징행동 점 수가 2.29점으로 나타나 청각장애 영유아가 각각 0.04점, 0.86 점, 1.14점 더 많은 점수 증가량을 보였으나, 두 그룹의 증가량 은 통계적으로 유의미하게 다르지 않았다 $(p>0.05)$.

$\mathrm{CSBS} \mathrm{DP}$ 행동 샘플로 평가한 청각장애 영유아의 점수는 재 활 전과 후의 사회적 행동 점수는 52.58점(SD: \pm 12.24$)$ 과 60.00점(SD: \pm 6.93), 언어 표현 점수는 22.13점(SD: \pm 2.10$)$ 과 23.88점(SD: \pm 2.59$)$, 상징행동 점수는 26.25점(SD: \pm 11.87$)$ 과 31.75점(SD: \pm 7.27)이었고 통계적으로 유의미한 차이는 보 이지 않았다 $(p>0.05)$. 검사 매뉴얼에 제시된 본 연구 대상자 들의 재활 전후 연령에 해당하는 정상 영유아의 규준 사회적 행동 점수는 44.63점(SD: \pm 2.69$)$ 에서 46.13점(SD: \pm 2.39$)$, 언 어 표현 점수는 17.88점(SD: \pm 8.68)에서 22.88점(SD: \pm 7.55$)$, 상징행동 점수는 23.75 점(SD: \pm 10.12$)$ 에서 29.50점(SD: \pm

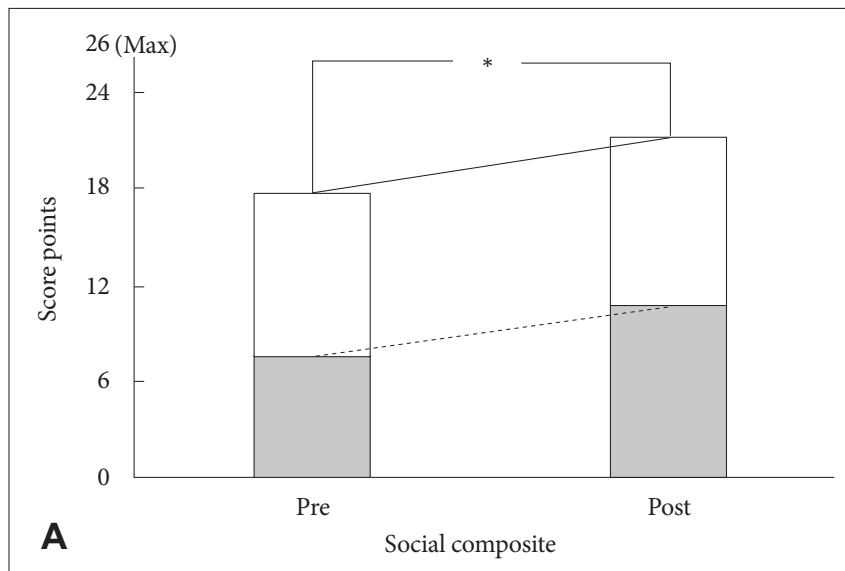

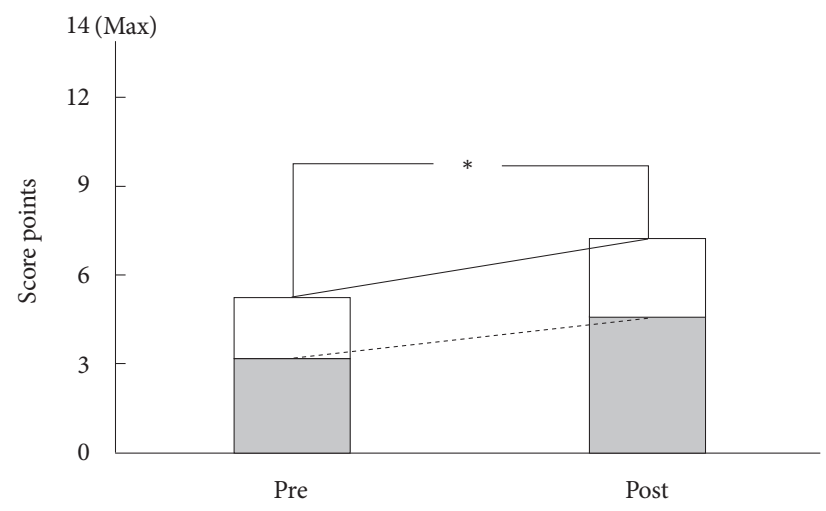

B

Speech composite

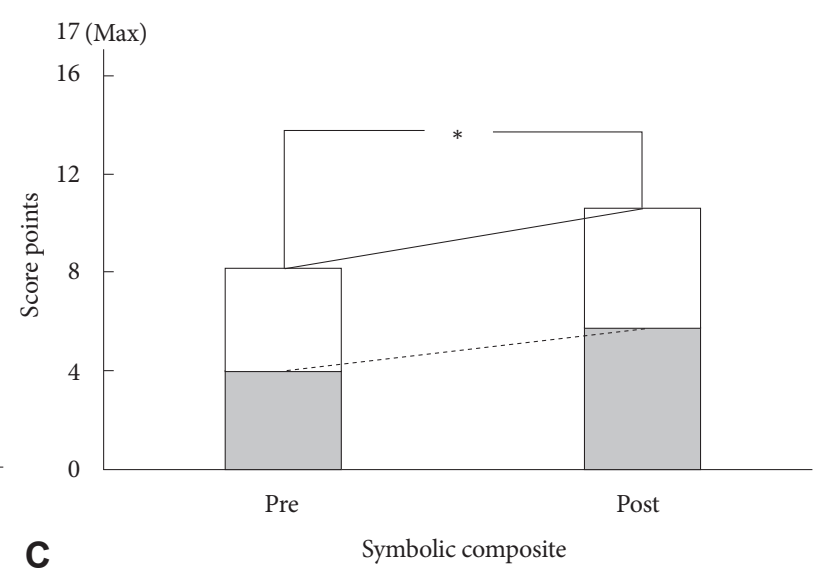

Figure 2. CSBS DP checklist scores at the pre- and post-rehabilitations. A: CSBS DP checklist social composite. B: CSBS DP checklist speech composite. C: CSBS DP checklist symbolic composite. The grey bars and dotted lines show the normal means provided by the manual and the white bars and solid lines show the scores of the hearing-impaired babies. ${ }^{*} p<0.05$. CSBS DP: Communication and Symbolic Behavior Scales: Developmental Profile, KARI: Korean Auditory, language, and cognitive Rehabilitation for Infants. 
6.84)이었다. 따라서 청각장애 영유아의 재활 전후 점수 증가량 과 해당 기간 동안 정상 영유아의 동일 연령 규준 점수 증가량 은 사회적 행동 점수가 7.43 점과 1.50 점, 언어 표현 점수가 1.75 점과 5.00점, 상징행동 점수가 5.50점과 5.75점이었고 통계적으 로 유의미한 차이를 보이지는 않아 두 그룹 간 증가량 차이가 다르지 않은 것으로 나타났다 $(p>0.05)$ (Figure 2).

\section{발달 선별}

전반적 발달을 평가하기 위하여 실시한 K-DST의 재활 전 청 각장애 영유아와 동일 연령 정상 영유아의 점수는 대근육운동 은 17.22점(SD: \pm 6.76)과 20.89점(SD: \pm 3.76 , 소근육운동은 21.44점(SD: \pm 3.21)과 22.00점(SD: \pm 2.06$)$, 인지는 18.00점(SD: \pm 4.06)과 19.44점(SD: \pm 2.55), 언어는 14.67점(SD: \pm 7.14)과 16.11점(SD: \pm 5.13$)$, 사회성은 19.56점(SD: \pm 3.84)과 18.89점 $(\mathrm{SD}: \pm 4.99)$, 자조는 18.50점(SD: \pm 0.71)과 18.00점(SD: \pm 4.24)이었고, 재활 후 청각장애 영유아와 동일 연령 정상 영 유아의 점수는 대근육운동은 20.51점(SD: \pm 1.03 )과 20.82점 $(\mathrm{SD}: \pm 0.92)$, 소근육운동은 20.82점(SD: \pm 0.70)과 20.40점 $(\mathrm{SD}: \pm 1.05)$, 인지는 20.19점(SD: \pm 1.06$)$ 과 20.12점(SD: \pm 0.87), 언어는 18.90점(SD: \pm 1.58 과 19.78점(SD: \pm 1.12 ), 사회성은 19.73점(SD: \pm 0.80)과 19.72점(SD: \pm 0.87$)$, 자조는 19.50점(SD: \pm 0.15$)$ 과 19.50점(SD: \pm 0.15$)$ 으로 거의 모든 영 역에서 각 연령대의 규준 점수와 다르지 않게 나타났고 통계적 유의성도 없었다 $(p>0.05)$.

\section{DISCUSSIONS}

본 연구를 통해 LEAQ-K, IT-ACBC, SELSI의 수용과 표현 언어, $\mathrm{K} \mathrm{MB} \mathrm{CDI}$ 의 이해 어휘, $\mathrm{CSBS} \mathrm{DP}$ 체크리스트의 사회적 행동, 언어 표현, 상징행동 등에서 재활 전후 점수에 통계적 유 의성이 나타나서 조기중재의 효과를 입증하였다. 또한 이런 중 재 전후 점수의 증가량을 해당 연령의 정상 영유아의 규준 점 수 증가량과 비교하였을 때, $\mathrm{K} \mathrm{MB} \mathrm{CDI}$ 의 제스처와 놀이 점수 를 제외하고 두 그룹의 점수 증가량 차이가 유의미하지 않아 청각장애 영유아가 정상 영유아의 발달의 속도로 발달하는 결 과로 나타났다. 듣기 발달 영역을 평가에서 청각장애 영유아의 중재 전후 LEAQ-K 검사 결과는 23.27점과 27.55점으로 Sohn et al.(2015)이 보고한 해당 연령의 정상 영유아 점수인 17.51점 과 21.98점을 모두 상회하여 듣기능력은 정상보다 더 좋은 점 수를 나타냈다. 아마도 청각장애 영유아로 초기부터 듣기능력 이 강화된 환경에 영유아가 적응한 것으로 생각된다. $\mathrm{CAP}$ 평 가에서는 재활 전후에 답변 단계 평균이 4.14에서 4.36으로 조 금 상승하였으나 통계적으로 유의미한 결과는 보이지 않았다.
아마도 CAP 평가도구는 주로 인공와우 사용자를 대상으로 듣 기 기능 변화를 장기간 추적하기 위해 개발되었고, 답변 단계 4 는 ‘독화 없이 약간의 말소리 변별, 5 는 ‘독화 없이 일상적인 구 문 이해', 6 은 '대화 이해'로 구성되어 있기 때문인 것으로 생각 된다. CAP 검사로 평균 4세 5개월에 인공와우를 착용한 영유 아 39명을 추적 관찰한 연구에서 인공와우 재활 시작한 지 6개 월 후에 39 명 중 $50 \%$ 가 4단계, 5 단계가 24개월 후에, 6 단계가 60개월 후에 나타난 것으로 보고되었다(Kim et al., 2002). 이 연구의 재활 시작 시기는 4 세 5 개월 이후로 본 연구의 재활 시 작 시기인 10.3 개월과 많은 차이가 있다. 따라서 거의 정상에 가까운 6 단계 달성이 재활 후 60 개월, 즉 거의 만 5 년이 걸렸던 것이고 본 연구는 8.1 개월 만에 거의 정상 수준의 의사소통능 력이 나타난 것으로 생각된다. 그러나 본 연구에 참여한 청각장 애 영유아 대상자 중 인공와우 착용자는 총 2명이므로 CAP 점 수의 직접적 비교는 불가능하였다. 더욱이 IT-ACBC 평가에서 도 청각장애 영유아의 결과가 해당 연령 정상 영유아의 결과보 다 좋은 점수를 보였으며, 재활 전후 청각장애 영유아들의 점 수 증가가 $13.48 \%$ 로 정상 영유아의 규준 증가인 $11.46 \%$ 보다 통계적으로 유의미하게 더 크게 나타나서 KARI 프로그램을 적용한 본 연구의 대상자들은 해당 연령의 정상 영유아보다 듣 기 영역의 발달이 빠르게 발달하는 것으로 분석되었다.

SELSI를 이용한 전반적 언어 발달 평가 결과, 재활 전후 수 용과 표현 언어 점수의 증가량은 해당 연령의 정상 영유아 규 준 점수의 증가량보다 높게 나타났으며, 재활 전후의 점수 증가 도 해당 연령 정상 영유아의 점수 증가량과 차이를 보이지 않 아 정상 또래 영유아와 유사한 발달을 보이는 것으로 나타났 다. 특히, $\mathrm{K} \mathrm{MB} \mathrm{CDI로} \mathrm{평가한} \mathrm{어휘} \mathrm{발달} \mathrm{영역에서} \mathrm{이해} \mathrm{어휘,}$ 표현 어휘, 제스처와 놀이의 재활 후 평가 점수가 전 영역에서 동일 연령의 50\%ile 규준 점수를 상회하였다(Pae \& Kwak, 2011). 이러한 결과는 본 연구 대상자의 언어 발달 수준이 재활 후 검사에서 거의 정상 수준인 것을 보여준다. 그러나 인공와 우를 착용한 아동에게 21.5 개월부터 재활을 시작한 경우의 $\mathrm{K}$ $\mathrm{MB} \mathrm{CDI}$ 검사에서 표현 어휘 수는 0.7 개에서 6 개월 후 26 개, 1 년 후는 130.2 개, 이해 어휘 수는 3.9 개에서 6개월 후 21.5개, 1년 후 는 184.3개로 증가한 결과를 보고하여(Yoon \& Choi, 2010) 정상 해당 연령의 $50 \%$ ile의 규준 점수에 미치지 못하였다. 더욱이 평 균 8.1개월의 중재에서 나타났던 본 연구의 표현 어휘의 점수인 34.36점, 이해 어휘 점수인 80.27점은 선행 연구의 6개월 후의 점수를 횔씬 상회하고 1년 후의 점수보다는 적었으나 이 차이 는 대상자들의 연령을 고려하면 본 연구 대상자들의 점수가 매 우 높은 수준인 것을 확인할 수 있다. 동일 연구에서 전반적 언 어 발달 평가인 SELSI 검사는 표현 언어 점수가 재활 전 9.2점 에서 6개월 후는 20.1점, 1년 후 33.6점으로 증가하였고, 수용 언 
어 점수는 12점에서 6개월 후 25점, 1년 후는 31.7점으로 증가한 결과로 본 연구 대상자들이 횔씬 어린 나이임에도 불구하고 표 현 및 수용 언어의 점수가 선행 연구의 5 세와 6 세 사이의 점수 로 나타나서 본 연구의 재활 효과가 상당히 좋고 언어 영역의 발 달이 빠른 것으로 분석할 수 있다. 따라서 재활 시작 연령이 어 릴수록 재활 효과가 좋은 것으로 결론 지을 수 있다.

발성 및 조음 영역은 Nathani et al.(2006)이 보고한 The Stark Assessment of Early Vocal Development-Revised (SAEVD$\mathrm{R})$ 가 보편적으로 국내외에서 여러 연구에 사용되고 있다. 그러 나 영어권과 우리나라 영유아의 발성 및 조음 유형의 차이를 보여 국내 영유아에게 적합한 발성 및 조음 발달 평가에 제한 점이 있어 최근 한국어를 모국어로 하는 국내 영유아의 발성 및 조음 발달 순서를 체계적으로 분석한 KIVAD로 평가하였다 (Kim et al., 2017). 그러나 2017년에 개발이 완성되어 본 연구의 사례는 4명만 KIVAD로 평가할 수 있었다. 따라서 SAEVD-R 의 평가 결과를 비교하기 위하여 KIVAD 중 발성을 검사한 KIVAD_Vocalization의 결과를 점수화하였는데, 점수화 방법은 $1,2,3,4,5$ 단계를 점수로 환산한 후 각 단계의 발성 비율을 곱 하여 합산해 발화 단계를 점수로 환산하였다. KIVAD로 평가 한 4명 영유아의 재활 전후 평가 점수 결과는 1.77점과 2.18점 으로 나타났고 SAEVD-R로 환산한 12명의 재활 점수 결과는 2.23점과 2.48점으로 나타나서 KIVAD 점수의 재활 전후 증가 량이 더 크게 나타났다. 이러한 KIVAD 점수의 조금 더 큰 변 화량은 이미 KIVAD의 원저자가 밝힌 대로 월령 구간에 따른 발성 발달이 영어권과 국내 영유아에 따라 차이가 있기 때문이 다. 예를 들어 월령 구간 1 2개월의 발성에서 영어권의 영유아 는 1단계에서 3단계까지 다양한 발성이 나오는 반면, 국내 영유 아는 1단계가 가장 많이 산출되며 3단계는 거의 산출되지 않는 다. 하지만 월령 구간이 높아짐에 따라 빠르게 발성 단계가 높아 져 KIVAD가 SAEVD-R에 비해 더 큰 증가량을 보인 것으로 생각할 수 있다.

사회적 의사소통 영역에서는 언어가 아닌 비언어적 수단을 이용한 의사소통 발달에 평가의 초점을 맞추고 있다. Wetherby \& Prizant(2002)가 보고한 동일 연령 정상 영유아의 CSBS DP 체크리스트 점수와 비교하였을 때, 전 영역에서 청각장애 영유 아의 재활 전후 점수 증가량은 정상 영유아의 동일 연령 규준 의 점수 증가량보다 높고 재활 전과 후의 점수도 높게 나타나서 본 연구 대상자 평균 연령인 10.3 개월은 본격적으로 한 단어로 말을 하기 시작하는 12 개월 이전이므로 비언어적 수단을 이용 한 사회성 능력은 정상 영유아보다 청각장애 영유아가 더 좋은 것으로 나타났다. 그러나 CSBS DP 행동 샘플과 K-DST의 대 상자 수는 4명과 9명으로 통계적 유의성을 구하기에 어려운 결 과여서 차후 대상자 수를 보완하면 유의미한 결과를 얻을 수
있을 것으로 생각된다.

본 연구 결과를 종합하면, 재활 전후에 듣기 발달 영역, 어휘 영역, 사회적 의사소통 영역 모두 해당 기간 동안 동일 연령의 정상 영유아의 점수 증가량을 상회하였고, 언어 영역과 발성 및 조음 영역은 정상 영유아의 점수 증가량과 유사하게 나타났다. 특히 전반적 언어능력과 어휘능력발달검사인 SELSI와 K MB $\mathrm{CDI}$ 검사 결과, 청각장애 영유아의 재활 전후 평가 점수는 동 일 연령 정상 영유아의 50\%ile 점수와 비슷하거나 상회하는 점 수를 보여 전 영역에서 KARI의 적용으로 조기재활이 효과적 인 것으로 나타났다.

인공와우 착용 후 조기중재 및 재활의 중요성은 여러 연구로 도 입증되었는데, 예를 들면 양이 인공와우를 5 개월과 15 개월 에 착용하고 조기재활을 받은 아기를 4년 동안 추적 관찰한 결 과, 전체적으로 정상 발달에 $95 \%$ 이상의 점수를 보여 2세 이전 의 조기중재가 효율적임을 입증하였고(Schauwers et al., 2004), 선천성 난청 영아의 인공와우 착용 나이를 1 2세, 2 3세, 3 4 세의 3 개 그룹으로 나누어 어음 인지 및 발화를 인공와우 착용 12 개월 후 구화에 의한 의사소통 방식을 사용하는 비율로 비 교하였을 때 1 2세는 85\%, 2 3세는 30\%, 3 4세는 18\% 등의 결과를 보여, 인공와우 착용 나이가 어릴 경우 정상에 가까운 구화 의사소통 비율을 보였다(Tait et al., 2007). 또한 인공와우 와 보청기를 착용하고 조기중재를 받은 영유아 24 명과 정상 발 달 영유아 163 명에게 영유아의 청각통합능력검사(Infant-Toddler Meaningful Auditory Integration Scale)로 초기 청각 기 술과 Production Infant Scale Evaluation으로 발화능력을 검 사하고 비교하였을 때, 높은 상관계수 $(r=0.89$ 와 $r=0.93)$ 를 보 여 영유아에서 초기 청각통합능력이 발화능력과 상관이 있고 서로 상호 보완적인 것으로 나타났다(Kishon-Rabin et al., 2005). 이러한 결과는 조기중재 및 조기 청각 기술은 구화로 하 는 의사소통 방식과 발화능력 발달에 매우 큰 영향을 미치고 아동 발달에 중요한 역할을 하는 것으로 해석할 수 있다.

KARI 프로그램은 특히 재활에 부모의 참여를 강조하였다. 부모와 아기가 함께 스킨십과 상호작용 놀이를 할 수 있도록 애 착 육아를 적용하였고, 가정에서 할 수 있는 16 가지 일상생활에 서 부모가 직접 사용할 수 있도록 되어 있고 부모가 아기에게 적극적으로 실시할 수 있는 재활 방법을 구체적으로 제시하였 다. 이와 같이 부모의 역할을 강조한 가족 중심의 프로그램을 이용하여 조기재활을 실시한 연구에서 인공와우를 착용한 아 동 15 명에게 청각 및 언어재활을 8 개월 동안 주 2 회씩 실시하 여 정상 능력인 ' 1 '을 기준으로 재활 전후의 능력을 비교하였을 때 인지능력은 0.57 에서 1.02 로, 사회적 의사소통능력은 0.41 에 서 0.91 로, 운동능력은 0.89 에서 1.3 으로 청각장애 아동이 또래 와 유사하거나 상회하는 발달을 보여(Jeddi et al., 2014) 조기중 
재로 여러 영역이 정상 청력 아동과 같은 발달이 나타나 부모 참여의 중요성이 입증되었다.

결론적으로 본 연구를 통해 언어 및 의사소통 발달은 인지, 운동, 사회 정서적 발달에 상관관계가 있고 청각장애가 있을 경 우 영유아 시기에 구조화되고 체계적인 청각언어인지재활을 할 경우 언어 발달뿐 아니라 여러 영역의 발달도 촉진시키는 것으 로 나타났다. 더욱이 조기중재, 특히 12 개월 이전에 시작하는 청각언어인지재활은 정상과 거의 유사한 발달을 이끌 수 있는 결과를 가져올 수 있다는 것이 매우 의의가 있다. 향후 더 많은 청각장애 영유아에게 KARI와 같은 구조적인 재활이 적용되어 정상적인 청각 및 언어 발달과 여러 영역의 발달도 함께 향상될 수 있다는 연구가 진행되어야 할 것이며, KARI 등의 조기중재 프로그램 연구도 더 심도 있게 진행되어야 할 것으로 생각한다.

\section{중심 단어 : 영유아-청각재활-한국형 영유아 청각언어인지재} 활·조기중재·청력손실.

\section{Ethical Statement}

The entire procedure including participant recruitment, testing, compensation, and data handling followed the protocol approved by the Institutional Review Board of the Hallym University (HIRB-2015-007).

\section{Acknowledgments}

The authors thank to Hyejin Park, Jieun Yoon, Kyeongyeon Park, and Jihyeon Lee for their effort and time for collecting data and the participants and their parents.

\section{Declaration of Conflicting Interests \\ There are no conflict interests.}

\section{Funding}

This work was supported by the Ministry of Education of the Republic of Korea and the National Research Foundation of Korea (NRF- 2015 S1A5A2A0101 1541).

\section{Author Contributions}

This work was designed and directed by J.K. and D.K. D.K. and H.Y. verified and validated the methodology. H.Y. analyzed the data and wrote the draft. The final version of manuscript was written and reviewed by J.K.

\section{ORCID iDs}

Heesoon Yoo

Jinsook Kim

https://orcid.org/0000-0002-5262-3264

https://orcid.org/0000-0003-3440-2393

\section{REFERENCES}

American Academy of Pediatrics, Joint Committee on Infant Hearing. (2007). Year 2007 position statement: Principles and guidelines for early hearing detection and intervention programs. Pediatrics, 120(4), 898921

Archbold, S., Lutman, M. E., \& Marshall, D. H. (1995). Categories of auditory performance. Annals of Otology, Rhinology and Laryngology. Supplement, 166, 312-314.

Ertmer, D. J., Young, N., Grohne, K., Mellon, J. A., Johnson, C., Corbett, K., et al. (2002). Vocal development in young children with cochlear im- plants: Profiles and implications for intervention. Language, Speech, and Hearing Services in Schools, 33(3), 184-195.

Eun, B. L. \& Chung, H. J. (2014). Korean-Development Screening Test for Infants and Children (K-DST). Cheongju: Korea Centers for Disease Control and Prevention.

Fenson, L., Dale, P. S., Reznick, J. S., Thal, D., Bates, E., Hartung, J. P., et al. (1993). MacArthur Communicative Development Inventories: User's Guide and Technical Manual. San Diego, CA: Singular Publishing Group.

Jeddi, Z., Jafari, Z., Motasaddi Zarandy, M., \& Kassani, A. (2014). Aural rehabilitation in children with cochlear implants: A study of cognition, social communication, and motor skill development. Cochlear Implants International, 15(2), 93-100

Kim, J. S., Ji, Y. S., \& Shin, H. U. (2012). A Study of infant's vocal production patterns for developing early aural rehabilitation program. Audiology and Speech Research, 8(1), 61-77.

Kim, J., Yoon, J., Park, H., Park, K., \& Lee, J. (2017). The development of Korean infant vocal and articulatory development list. Audiology and Speech Research, 13(2), 141-160.

Kim, L. S., Lee, M. Y., Heo, M. J., \& Oh, Y. J. (2002). Long-term development of auditory performance in children with cochlear implants. Korean Journal of Otorhinolaryngology-Head and Neck Surgery, 45(1), 1821.

Kim, S. H., Lee, Y. H., Hwang, J. H., Oh, M. A., Lee, M. K., Lee, N. H., et al. (2014). 2014 Disabled People Status Survey. Sejong: Korea Institute for Health and Social Affairs.

Kim, Y. T., Kim, K. H., Yoon, H. R., \& Kim, H. S. (2003a). Sequenced Language Scale for Infants. Seoul: Paradise Welfare Foundation.

Kim, Y. T., Sung, T. J., \& Lee, Y. K. (2003b). Preschool Receptive-Expressive Language Scale. Seoul: Seoul Community Rehabilitation Center.

Kishon-Rabin, L., Taitelbaum-Swead, R., Ezrati-Vinacour, R., \& Hildesheimer, M. (2005). Prelexical vocalization in normal hearing and hearing-impaired infants before and after cochlear implantation and its relation to early auditory skills. Ear and Hearing, 26(4 Suppl), 17S-29S.

Lee, J. Y. \& Jang, Y. K. (2004). The preliminary study for the standardization of CSBS infant-toddler checklist. The Korean Journal of Human Development, 11(4), 37-54.

Lee, M. S. \& Cho, S. J. (2011). A case report on aural rehabilitation after cochlear implantation in a child with LEOPARD syndrome. The Journal of Special Children Education, 13(3), 357-370.

Nathani, S., Ertmer, D. J., \& Stark, R. E. (2006). Assessing vocal development in infants and toddlers. Clinical Linguistics and Phonetics, 20(5), 351-369.

National Institutes of Health. (1993). Early identification of hearing impairment in infants and young children. NIH Consens Statement, 11(1), 1-24.

Noh, J. A. (2014). Research trends of parent-implemented interventions for young children with special needs and application of the WWC standards: Single case studies. The Journal of Special Children Education, 16(2), 425-453.

Pae, S. Y. \& Kwak, K. J. (2011). Korean MacArthur-Bates Communicative Development Inventories (K M-B CDI) User's Guide and Technical Manual. Seoul: Mindpress.

Park, H. \& Kim, J. (2016a). Comprehension and application of the ling 6 sound test. Audiology and Speech Research, 12(4), 195-203.

Park, K. \& Kim, J. (2016b). A developmental study for infant-toddler auditory \& communicative behavioral checklist. Audiology and Speech Research, 12(2), 65-73.

Rhoades, E. A. \& Duncan, J. (trans. Yoon, M. S., Chang, S. A., Park, H. O., \& Lee. M. S.) (2016). Auditory-Verbal Practice: Toward a Family-Centered Approach. Seoul: Hakjisa.

Rossi, K. (2003). Learn to Talk Around the Clock: A Professional's Early Intervention Toolbox. Washington, DC: Alexander Graham Bell Association for the Deaf and Hard of Hearing.

Schauwers, K., Gillis, S., Daemers, K., De Beukelaer, C., De Ceulaer, G., Yperman, M., et al. (2004). Normal hearing and language development 
in a deaf-born child. Otology and Neurotology, 25(6), 924-929.

Sohn, M., Kim, J., \& Park, H. (2015). Auditory development assessment with LittlEARS $\AA$ auditory questionnaire in children with and without hearing loss. Audiology and Speech Research, 11(1), 45-62.

Tait, M. E., Nikolopoulos, T. P., \& Lutman, M. E. (2007). Age at implantation and development of vocal and auditory preverbal skills in implanted deaf children. International Journal of Pediatric Otorhinolaryngology, 71(4), 603-610.

Watkins, S., Taylor, D. J., \& Mikalich, E. (2004). SKI-HI Curriculum: Family-Centered Programming for Infants and Young Children with Hearing Loss. Logan, UT: Utah State University,

Wetherby, A. M. \& Prizant, B. M. (2002). Communication and Symbolic Behavior Scales Developmental Profile (CSBS DP). (1st ed.). Baltimore, MD: The Brookes Publishing.

WHO. (2013). Multi-Country Assessment of National Capacity to Provide Hearing Care. Geneva: World Health Organization.
Yoo, H. \& Kim, J. (2018). Attachment parenting and auditory, language and cognitive rehabilitation. Audiology and Speech Research, 14(1), 11-22.

Yoon, J., Kim, J., \& Park, H. (2016). Early auditory rehabilitation of an infant with unilateral profound hearing loss: A case study. Audiology and Speech Research, 12(2), 115-125.

Yoon, M. S. \& Choi, E. A. (2010). Early intervention for children with hearing impairment: Assessment of communication abilities. Communication Sciences and Disorders, 15(1), 1-19.

Yoshinaga-Itano, C. \& Apuzzo, M. L. (1998). Identification of hearing loss after age 18 months is not early enough. American Annals of the Deaf, 143(5), 380-387.

Yoshinaga-Itano, C., Coulter, D., \& Thomson, V. (2000). The Colorado Newborn Hearing Screening Project: Effects on speech and language development for children with hearing loss. Journal of Perinatology: Official Journal of the California Perinatal Association, 20(8 pt 2), S132S137. 


\section{Appendix 1. CSBS DP 체크리스트}

\section{CSBS DP CSBS DP Infant-Toddler Checklist}

아동 이름:

미숙아 여부:

작성자:
생일:

작성일:

미숙아인 경우: 주

아동과의 관계:

설명: 본 체크리스트는 영유아의 다양한 발달적 측면을 확인하기 위해 개발되었습니다. 아동의 언어 발달 이전 행동은 아동이 언어 습득에 어려움이 있는지를 보여줄 수 있습니다. 본 체크리스트는 6 24개월 영유아의 심화평가의 필요성을 파악하기 위해 반드시 주 양육자가 기 록해야 합니다. 주 양육자는 부모 혹은 아동을 매일 돌보는 사람입니다. 아동의 행동을 가장 잘 설명하는 보기에 모두 체크해주세요. 확실 하지 않은 경우 아동의 평소 행동을 참고하여 가장 가까운 보기를 고르세요. 6 24개월 아동이 다음의 행동을 모두 다 수행하지 않을 수도 있습니다.

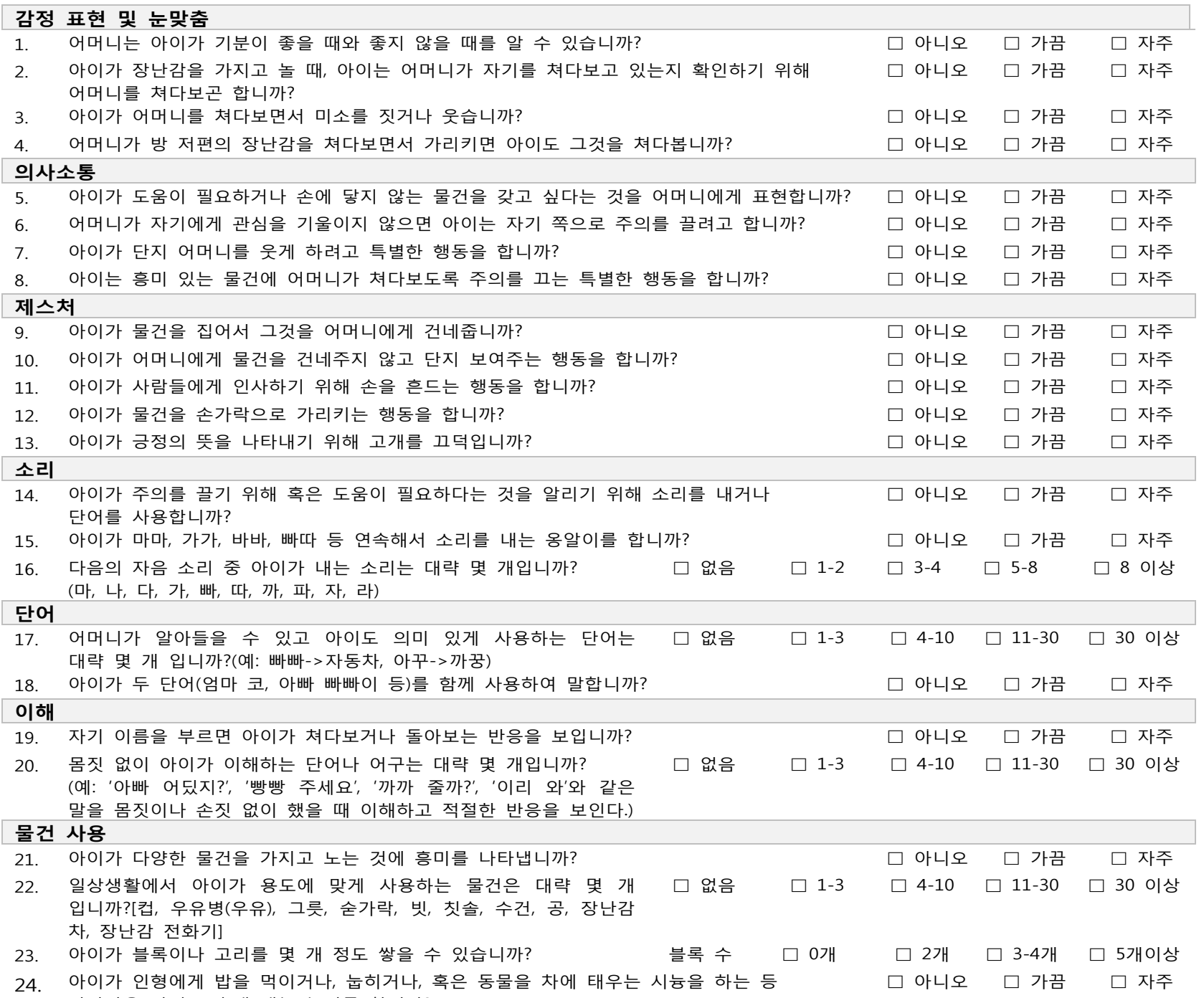


Appendix 2. 한국형 영유아를 위한 청각언어인지재활(Korean Auditory, language, and cognitive Rehabilitation for Infants)의 구성

\begin{tabular}{|c|c|c|c|}
\hline Category & & Item & Contents \\
\hline \multirow{2}{*}{$\begin{array}{l}\text { 회기 전 } \\
\text { 점검 목록 }\end{array}$} & \multicolumn{2}{|c|}{ 회기 계획 및 보고서 } & $\begin{array}{l}\text { 재활 목표, 계획, 회기별 점검 목록 등을 한눈에 보고 체크할 수 있도록 정리한 } \\
\text { 영유아 조기 청능재활 계획 및 보고서 }\end{array}$ \\
\hline & \multicolumn{2}{|c|}{ 궁금해요 } & $\begin{array}{l}\text { 청각보조기기 및 재활 관련 상담 내용을 주간별로 정리하여 부모와 전문가가 교류할 } \\
\text { 수 있도록 구성된 알림장 }\end{array}$ \\
\hline \multirow{3}{*}{$\begin{array}{l}\text { 전문가용 } \\
\text { 자료 }\end{array}$} & \multicolumn{2}{|c|}{ 기간 점검표 } & $\begin{array}{c}\text { 1 3, 4 5, 6 7, 8 9, 10 11, 12 13, 14 15, 16 17, 18 19, 20 21, } \\
22 \sim 24 \text { 개월 등 11개 연령으로 구분하여 목표 발성 및 자음 목록 제시 }\end{array}$ \\
\hline & \multicolumn{2}{|c|}{ Ling 6 sound } & $\begin{array}{l}\text { 영유아의 청각 상태와 현재 청각보조기기의 주파수 분석능력을 확인하기 위하여 } \\
\text { /아/, /이/, /우/, /음/, /스/, /쉬/의 6개 음소로 구성된 듣기능력검사 }\end{array}$ \\
\hline & \multicolumn{2}{|c|}{$\begin{array}{l}\text { 영유아의 청각/언어재활 } \\
\text { 가이드라인 }\end{array}$} & $\begin{array}{l}\text { 영유아의 청각언어인지재활을 효율적으로 실행할 수 있도록 전문가를 위한 구체적 } \\
\text { 재활 가이드라인을 체계적으로 정리한 지침 }\end{array}$ \\
\hline \multirow{6}{*}{$\begin{array}{l}\text { 부모 } \\
\text { 교육자료 }\end{array}$} & \multirow{3}{*}{$\begin{array}{l}\text { 스마트 } \\
\text { 육아법 }\end{array}$} & 애착육아법 & $\begin{array}{l}\text { 전반적 영역과 청각·언어영역의 뇌 발달 촉진을 위하여 안정적으로 양육자와 아기의 } \\
\text { 애착을 형성하도록 우리나라의 전통적 육아법, 수면 방법, 모유수유와 스킨십, } \\
\text { 상호작용 놀이법 등을 바탕으로 청각언어인지 능력을 향상하도록 제시한 육아법 }\end{array}$ \\
\hline & & 단동십훈 & $\begin{array}{l}\text { 단군시대부터 구전되어 온 신체 발달 및 성장을 돕는 전통놀이로 청각언어인지 } \\
\text { 발달에 도움이 되는 초기 자극 요소를 갖춘 반복적이고 쉬운 익숙한 운율과 } \\
\text { 동작을 함께할 수 있는 손쉬운 전통 놀이법 }\end{array}$ \\
\hline & & $\begin{array}{l}\text { 자기주도형 } \\
\text { 아기로 키워요 }\end{array}$ & $\begin{array}{l}\text { 자존감과 독립심을 향상시킬 수 있고 영유아 스스로 결정하도록 기회를 풍부히 } \\
\text { 주고 청각언어인지 발달을 촉진시킬 수 있도록 부모가 실천할 수 있는 방법을 } \\
10 \text { 개의 자가점검 목록을 포함하여 제시 }\end{array}$ \\
\hline & \multicolumn{2}{|c|}{$\begin{array}{l}\text { Short Fun Input for } \\
\text { Modeling }\end{array}$} & $\begin{array}{l}\text { 영유아의 집중 시간을 고려하며 쉽고 재미있게 영유아의 발성 및 조음 모방을 } \\
\text { 유도하는 구체적이고 효율적인 모델링 방법 }\end{array}$ \\
\hline & \multicolumn{2}{|c|}{$\begin{array}{l}\text { 우리아이와 매일매일 } \\
\text { 어떻게 말할까요 }\end{array}$} & $\begin{array}{l}16 \text { 개 일상적인 상황에서 청각언어인지재활을 적용하여 영유아의 발성 및 조음을 } \\
\text { 효율적으로 유도할 수 있는 대화 및 상호작용의 실제 방법 }\end{array}$ \\
\hline & \multicolumn{2}{|c|}{$\begin{array}{l}\text { 우리아이의 청각/언어 발달 } \\
\text { 촉진법 }\end{array}$} & $\begin{array}{l}\text { 영유아의 발성 및 조음 발달을 효율적으로 유도하기 위해 소리와 언어가 풍부한 } \\
\text { 환경에서 영유아에게 말할 때와 영유아가 말하도록 할 때를 구분하여 구체적인 } \\
\text { 촉진 방법을 제시 }\end{array}$ \\
\hline
\end{tabular}


Early Intervention Effect Using KARI

Appendix 3. 회기 계획 및 보고서

KARI 회기 계획 및 보고서

이름:

단기 계획

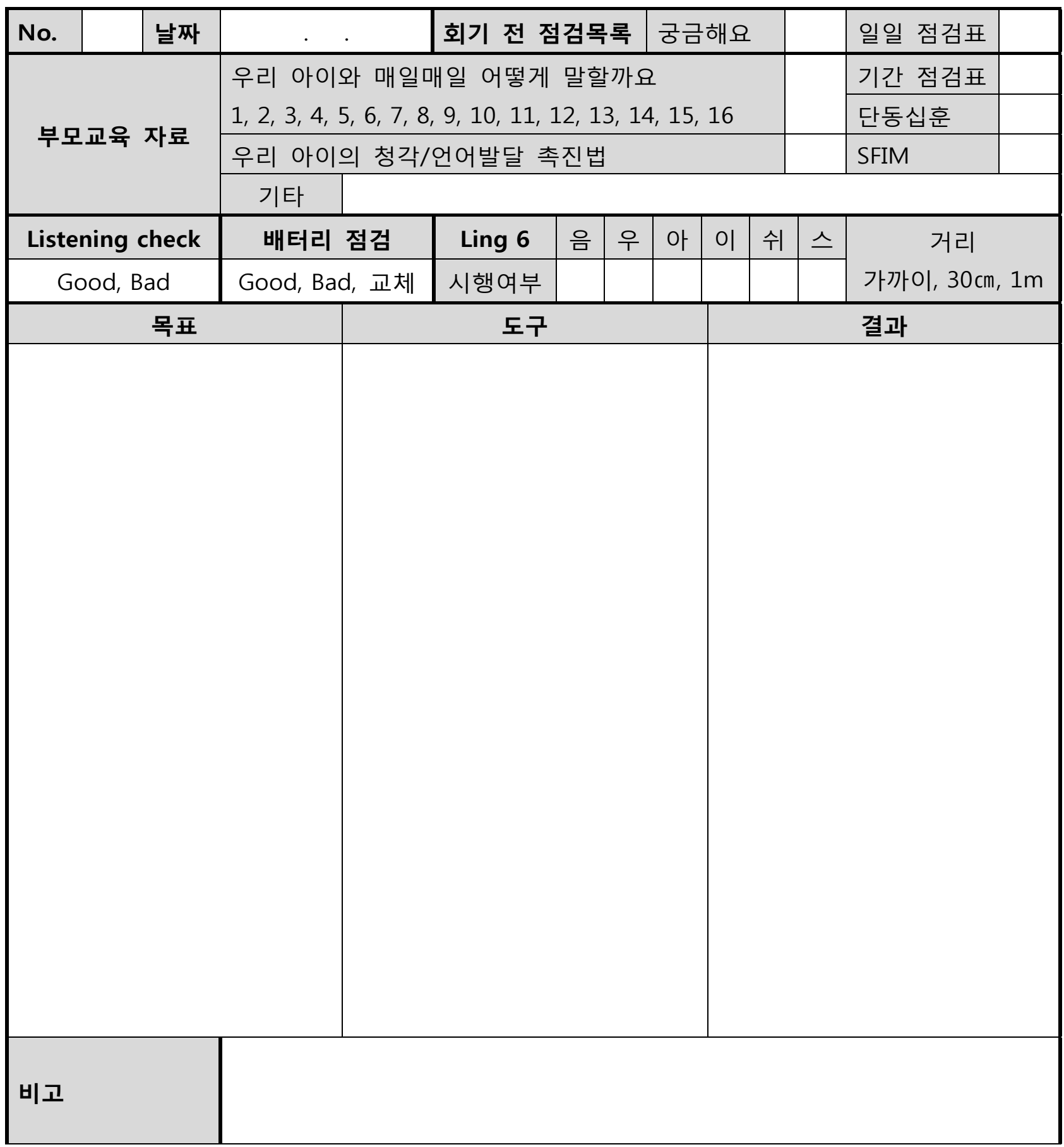

장기 계획 
Appendix 4. 기간 점검표의 예

KARI 기간 점검표(1 3개월)

아기 이름:

\begin{tabular}{|c|c|c|c|c|c|c|}
\hline 날짜 & $\begin{array}{c}\text { 아기가 스스로 한 } \\
\text { 발성이나 조음 }\end{array}$ & $\begin{array}{l}\text { 엄마가 } \\
\text { 한 말 }\end{array}$ & $\begin{array}{c}\text { 아기가 } \\
\text { 따라 한 } \\
\text { 말이나 } \\
\text { 행동 }\end{array}$ & $\begin{array}{c}\text { 우리 아기와 매일매일 } \\
\text { 어떻게 말할까요 }\end{array}$ & $\begin{array}{l}\text { 시행 } \\
\text { 여부 } \\
(O, X)\end{array}$ & $\begin{array}{l}\text { 질문 } \\
\text { /코멘트 }\end{array}$ \\
\hline $\begin{array}{r}20 \quad \begin{array}{r}\text { 년 } \\
\text { 월 }\end{array} \\
- \text { _ } \\
\\
\text { 일 }\end{array}$ & & & & $\begin{array}{c}\text { 아침에 일어날 때 } \\
\text { 기저귀 갈 때 } \\
\text { 목욕 전후 } \\
\text { 마사지할 때 } \\
\text { 젖 먹일 때 } \\
\text { 옷을 입고 벗을 때 } \\
\text { 아이에게 밥 먹일 때 } \\
\text { 책 읽기 } \\
\text { 공 가지고 놀기 } \\
\text { 인형(아기, 곰) 가지고 놀기 } \\
\text { 퍼즐 가지고 놀기 } \\
\text { 소꿉놀이하기 } \\
\text { 놀이터에서 놀기 } \\
\text { 색깔찰흘 놀이 } \\
\text { 빨래하기 } \\
\text { 산책하기 } \\
\text { 기타 활동: }\end{array}$ & & \\
\hline 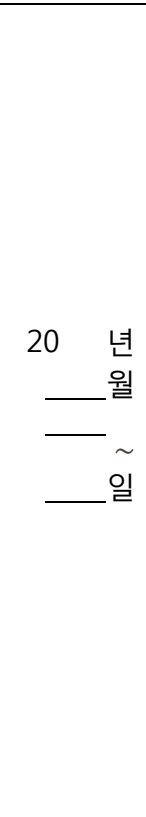 & & & & $\begin{array}{c}\text { 아침에 일어날 때 } \\
\text { 기저귀 갈 때 } \\
\text { 목욕 전후 } \\
\text { 마사지할 때 } \\
\text { 젖 먹일 때 } \\
\text { 옷을 입고 벗을 때 } \\
\text { 아이에게 밥 먹일 때 } \\
\text { 책 읽기 } \\
\text { 공 가지고 놀기 } \\
\text { 인형(아기, 곰) 가지고 놀기 } \\
\text { 퍼즐 가지고 놀기 } \\
\text { 소꿉놀이하기 } \\
\text { 놀이터에서 놀기 } \\
\text { 색깔찰흙 놀이 } \\
\text { 빨래하기 } \\
\text { 산책하기 }\end{array}$ & & \\
\hline
\end{tabular}

※ 상기의 16 개 활동 외 활동은 '기타 활동'에 적어주세요.

\begin{tabular}{|c|c|c|c|c|}
\hline \multicolumn{2}{|c|}{ 예측 발성 종류(KIVAD_V) } & \multicolumn{3}{|c|}{ 예측 조음 종류(KIVAD_AA) } \\
\hline $1 \sim 3 \mathrm{~m}$ & $4 \sim 5 \mathrm{~m}$ & 개월 & $1 \sim 3 \mathrm{~m}$ & $4 \sim 5 \mathrm{~m}$ \\
\hline \multirow{3}{*}{$\begin{array}{l}\text { VEG, CR, Q } \\
\text { Q2, F, F2, CV, } \\
\text { cV2, SQ }\end{array}$} & \multirow{3}{*}{$\begin{array}{c}(1 \sim 3 m)+V, V 2, \\
V g, C H, M B, C V \\
\text { CV-C, CVCV }\end{array}$} & 모음 & $/-/, / \|(H) /, /-1$ & $(1 \sim 3)+/ \vDash /, / \dashv /, / T /, / \mid /$ \\
\hline & & 초성자음 & - & /ᄀ/,/ロ/, //, /ㅂ/, /ㅍ/, /ட/, /ヨ/ \\
\hline & & 종성자음 & - & /०/,/ロ/ \\
\hline
\end{tabular}




\section{Appendix 5. 우리 아이의 청각/언어 발달 촉진법}

\section{우리 아이의 청각/언어발달 촉진 방법}

\section{아기에게 말할 때}

- 아기와 눈맞춤을 하고 모든 행동과 발성에 미소를 띄고 긍정적으로 코멘트하세요.

- 단순하고 짧은 행동과 말로 아기에게 이야기해 주세요.

- 아기가 집중하는 동안 목표 행동과 말을 반복적으로 하세요. 반복적인 행동과 말에 먼저 지루해지는 사람은 어른입니다. 재미있는 행동과 말을 계속 반복해도 아기들은 집중할 수 있습니다.

- 장난감으로 놀 때, 장난감의 위치는 얼굴 주변으로 하여 부모가 말하는 동안 아기가 집중할 수 있도록 하세요.

- 사물을 제시하기 전에 그 이름을 먼저 말하여 듣기 연습할 기회를 제공하세요. 예를 들어, '우유 먹을까?'라고 먼저 말한 후 우유를 주면 아기가 우유를 보기 전에 '우유'라는 단어를 듣고 생각할 기회를 갖습니다.

\section{아기가 말하도록 할 때}

- 아기의 발성과 행동을 관찰하고 발성하면 즉각적으로 따라 하세요.

- 차례차례하기(turn-taking) 놀이를 해보세요. 예를 들어, 아기가 /아 아/ 하면 동일한 억양으로 부모가 /아 아/ 하고 대답합니다. 그리고 다음은 아기가 말할 차례임을 아기의 눈을 보고 기다리는 행동으로 알려줍니다.

- 새로운 자발적 발성이나 조음이 나타나면 따라 하고, 그 발성이나 조음에 관련된 놀이를 이용하여 더 말해주세요.

- 발성이나 조음이 맞건 틀리건 발성을 이용하여 의사를 표현하면 칭찬해주세요. 이러한 과정이 말이나 발성 이용의 중요성을 알게 합니다.

\section{소리 및 언어가 풍부한 환경을 조성할 때}

- 아기가 집중하는 소리(예를 들어 차, 문, 노크, 초인종, 전화기 소리)를 관련된 놀이와 말로 연결해보세요.

- 청각/언어재활 시간이 재미없으면 더 이상 아기는 집중하지 않습니다. 특정 행동이나 발성을 너무 강요하지 말고 재미있는 시간을 만들어보세요. 부모와 아기 모두 재활 시간이 즐거워야 합니다.

· 책은 매일매일 읽어주세요. 